\title{
EXPERIMENTAL FOCAL EPILEPTIC SEIZURE AND ITS MARCH OF MOVEMENTS
}

\author{
TAKASHI HAYASHI* and ISAMU SUDA** \\ Department of Physiology, School of Medicine, \\ Keio University
}

(Received on November 20th, 1953)

\section{INTRODUCTION}

Experimental focal epileptic seizures following the stimulation of cerebral cortex in monkeys (maccacus cyclops) as well as in dogs may be divided into two types, i.e., the one was the focal type in which seizures were produced in a delimited part of the body, for example, in a limb which was determined by the stimulated site of cortex. This type corresponds with the epilepsia partialis continua in human epileptics. The other one was the focal type in which the seizure began in some part of the body and generalized at last into the whole body with the march of the movements in the sense of Hughlings Jackson(4).

Hayashi published a paper(1) dealing with the above classification, in which he reported that the former type was seen only in a few cases of experiments with monkeys, but not in dogs, when the electric stimulation as well as the chemical stimulation was used, and he did not know there should be chemicals which produced that type selectively. But recently in his laboratory, two special chemical substances which produced selectively this type when applied to the motor area of the cortex of the animals were found. They were solutions of sodium of glutathion and isonicotinic acid.

When electrical stimulation was used, in an appropriate strength, at first, contraction of a limb was produced, and when it was made stronger, contraction of one more limb was added, still stronger, in three limbs, at last in four limbs at the same time. $\dagger$

When the above strength which produced the contraction in one limbe was used and it was applied in a little bit longer duration, the contraction of the one limb gave the place to the clonic convulsion during the stimulation or after cessation of the stimulation, and the convulsion marched to the other limbs. When the strength was stronger such as one which produced contractions in two limbs,

* Professor in Physiology.

** Present address is: Professor in Physiology, Medical School, Kobe University.

$\dagger$ This phenomena, the adding of contracted limbs due to the progressive increase of the strength will be reported in another occasion. 
the case was quite the same i.e., the contractions of the two limbs gave the place to the clonic convulsions and it generalized to the other two limbs with a march. Of course the strength was to produce the contraction in four limbs at the same time, the clonic convulsion was produced in four limbs at the same time which would be called generalized epileptic seizure from the beginning. Thus, as to generalized epileptic seizures, they were divided into two types, the one may be generalized type with march from focal seizure, and the other, generalized type from the beginning.

The efferent pathway for epileptic seizure of face muscles differed from that for limbs (2), but in the generalization of clonic convulsion of face to and from the limbs in these two types, the march will occur in the same manner as between the limbs. Are there any rule in these march of movements of epileptic seizure in animals?

\section{LAW OF FINAL COMMON AREA IN CORTICAL EPILEPTIC SEIZURES}

1. The focal type with march was produced from the area 4 and 3-1-2, but the generalized from the beginning was produced from Area $6 \mathrm{a} \alpha$ in monkeys.

The experiments were made in monkeys, of which the skull was opened and the motor area was stimulated electrically or chemically and described the site of the stimulation according to the Vogts' diagram with cytoarchitectural areas as in Fig. 1.

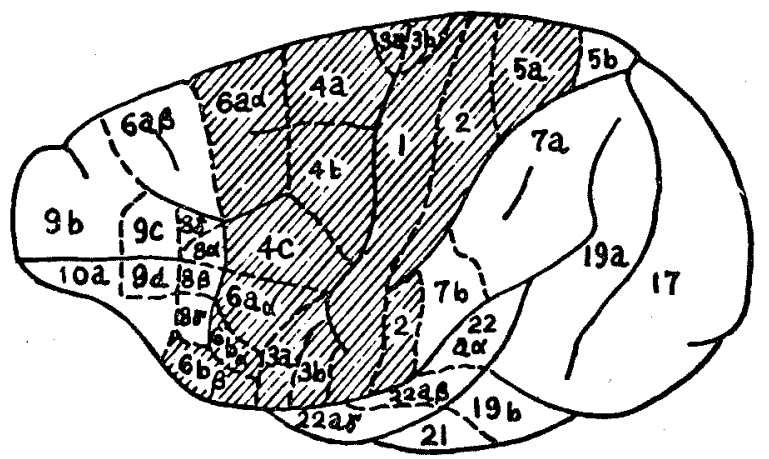

Fig. I Vogt's diagram of cytoarchitectural area of the monkey (redrawn and shaded by the authors)

The facts shown in Table 1 and 2 were quite same in dog experiments. In dogs, gyrus sigmoideus is the motor area for focal seizure with march for limbs, which correspond to the arm and leg area within the Area 4 'in monkeys. We 
called the area extended to proximal and also to caudal from the gyrus sigmoideus "extramotor area" which functionally corresponds with the Area 6, 1-2-3 in monkeys (indicated in Fig. 1 shaded).

Table 1

The focal type of generalized epileptic seizures was produced from area 4 and area $3-1-2$

\begin{tabular}{|c|c|c|c|}
\hline \multicolumn{3}{|c|}{ Experiment No. 1} & Monkey Female \\
\hline hr. & $\min _{0}$ & $\begin{array}{l}\text { sec. } \\
15\end{array}$ & $\begin{array}{l}\text { In the middle part of the right } 4 \mathrm{~b}, 0.05 \mathrm{cc} \text { of } 3 \% \text { picrotoxine } \\
\text { solution was introduced. }\end{array}$ \\
\hline & 6 & 45 & In the left fore limb, the clonic convulsion began. \\
\hline & 9 & 2 & It marched to the left hind limb. \\
\hline & 13 & 24 & It marched from the left hind limb to the right fore limb. \\
\hline & 14 & 9 & It marched to the right hind limb. \\
\hline & 15 & 45 & The seizures of all four limbs became stronger. \\
\hline & 16 & 24 & $\begin{array}{l}\text { At the point of the injected area, a part of the cortex was ex- } \\
\text { tirpated including around the site of injection. No change } \\
\text { in the seizures. }\end{array}$ \\
\hline & 37 & 0 & $\begin{array}{l}\text { Area } 4(4 \mathrm{a}, 4 \mathrm{~b}, 4 \mathrm{c}) \text { was totally extirpated at once. A moment } \\
\text { after the extirpation, the generalized seizures were ceased at } \\
\text { the same time. }\end{array}$ \\
\hline
\end{tabular}

Table 2

The generalized cpileptic seizure from the beginning was produced through the stimulation to area 6 ax

\begin{tabular}{|c|c|c|c|c|}
\hline \multicolumn{3}{|c|}{ Experiment No. 2} & Monkey & $5 \mathrm{k}_{\varepsilon}$. \\
\hline \multirow[t]{4}{*}{ hr. } & $\min _{0}$ & $\begin{array}{c}\text { sec. } \\
5\end{array}$ & \multicolumn{2}{|c|}{$\begin{array}{l}\text { The left area } 4 \mathrm{c} \text { was stimulated electrically (faradization } 0.5 \\
\text { second). The contraction of face muscle in the right cheek } \\
\text { was produced, and it ceased after the cessation of the sti- } \\
\text { mulus. }\end{array}$} \\
\hline & & 19 & \multicolumn{2}{|c|}{ The left area 6 a $x$ was stimulated (faradization 5 secs.). } \\
\hline & & 20 & \multicolumn{2}{|c|}{$\begin{array}{l}\text { In the face of both sides and the four limbs, the epileptic sei- } \\
\text { zures were produced all at once, and continued. }\end{array}$} \\
\hline & & 30 & \multicolumn{2}{|c|}{$\begin{array}{l}\text { The Area } 4 \mathrm{a}, \mathrm{b} \text {, c were extirpated, the seizures were ceased at } \\
\text { once after the extirpation was made. }\end{array}$} \\
\hline
\end{tabular}

Now, the above result raises a question: Does the irradiation from the point stimulated in Area 6 occurred instantaneously to the whole body and in the case of stimulation of Area 4 and 1-2 does it take the delayed time?

Hayashi has already reported the experiments in dogs(1) that after when the gyrus sigmoideus was extirpated, the stimulation of the extramotor area failed to produce the seizure; on the contrary, when under the site of stimulation of the extramotor area, the white matter was horizontally cut, the stimulation of the grey matter over it could produce the seizure.

$\mathrm{He}$ has also reported (3) that the mastication following the stimulation of 
the face area in dogs and that of the gyrus hippocampi had different physiological meaning, i.e., the former is the true motor center of mastication and the latter is the extramotor center of it, for the impulses from the latter were projected through the former. Here is also the motor and extramotor relation.

2. The impulses for epileptic seizures from Area 6 were projected through Area 4.

It is the fact that Hayashi called "the law of final common area(1)". The law means that the impulses for epileptic seizure which occurs in any extramotor area at first irradiate to gyrus sigmoideus and next from there project to the body muscle.

Does the same law be applied to the seizure of monkeys? Table 3 showed that it was confirmed exactly in monkeys.

It was quite clear that the impulses for epileptic seizure irradiated from Area 6 to Area 4, therefore the seizures would be stopped when Area 4 was totally removed. But there is one thing to be noticeable in this table. It is the results of the extirpation of small part of the site of stimulation in Area 4. The initiation of the movements would start here, without any spread of stimulation.

Table 3

The impulse for epileptic seizures from area $6 \mathrm{a}$ did not project to the muscles after the total extirpation of area 4

\begin{tabular}{|c|c|c|c|}
\hline \multicolumn{3}{|c|}{ Experiment No. 3} & Monkey \\
\hline \multirow[t]{3}{*}{$\begin{array}{l}\text { hr. } \\
14\end{array}$} & $\min _{0}$ & $\begin{array}{c}\sec . \\
5\end{array}$ & $\begin{array}{l}\text { The left area } 6 \text { a } x \text { was stimulated by faradization of } 5 \text { sece. of } \\
\text { duration. During the stimulation, the seizures appeared as } \\
\text { following. }\end{array}$ \\
\hline & & 10 & $\begin{array}{l}\text { The generalized seizures appeared in the face and four limbs } \\
\text { at the same time. }\end{array}$ \\
\hline & & 20 & $\begin{array}{l}\text { Area } 4(a, b, c) \text { was removed suddenly, the seizures were ceased } \\
\text { as the operation ended. }\end{array}$ \\
\hline \multirow[t]{8}{*}{15} & 0 & 15 & Picrotoxinization $(0.3 \%, 0.05 \mathrm{cc})$ in the middle of area $4 \mathrm{~b}$. \\
\hline & 6 & 45 & In the left fore limb, the seizure began. \\
\hline & 9 & 2 & The seizure marched to the left hind limb. \\
\hline & 13 & 24 & Further marched to the right fore limb. \\
\hline & 14 & 9 & It marched to the right hind limb. \\
\hline & 15 & 45 & The generalized epileptic seizures were strengthened. \\
\hline & 16 & $\begin{array}{l}15 \\
1 \\
24\end{array}$ & $\begin{array}{l}\text { The site of picrotoxinization was extirpated, the generalized } \\
\text { seizures continued. }\end{array}$ \\
\hline & & $\begin{array}{l}24 \\
37 \\
1 \\
45\end{array}$ & $\begin{array}{l}\text { The right area } 4(\mathrm{a}, \mathrm{b}, \mathrm{c}) \text { was totally removed, and the seizures } \\
\text { were suddenly ceased. }\end{array}$ \\
\hline
\end{tabular}

But notwithstanding expectation of being stopped in fact, seizures did not cease. 
Of course when the initiated site of stimulation of the extramotor area was removed, the seizure did not cease except the case of the total removal of Area 4 . So that Area 4 must have another meaning for the seizure besides the "law of final common area."

\section{LAW OF SUBSTITUTION WITHIN THE MOTOR AREA IN CORTICAL EPILEPTIC SEIZURES}

1. Are there any order of sequence of march when a focal seizure generalizes into the other parts?

In the experiments No. 1 above described, the seizures began in the left fore limb and irradiated as

left for limb $\rightarrow$ left hind limb $\rightarrow$ right hind limb $\rightarrow$ right fore limb.

The examples in other experiments are showed in Table 4.

Table 4

There are no definite sequences in the march of movements of cortical epileptic seizures (monkeys)

\begin{tabular}{|c|c|}
\hline $\begin{array}{l}\text { Numbers of } \\
\text { experiments }\end{array}$ & 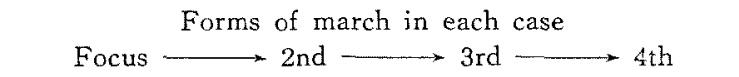 \\
\hline No. 1 & L.F.L. $\longrightarrow$ L.H.L. $\longrightarrow$ R.H.L. $\longrightarrow$ R.F.L. \\
\hline No. 2 & R.H.L. $\longrightarrow$ L.H.L. $\longrightarrow$ L.F.L. $\longrightarrow$ R.F.L. \\
\hline No. 3 & L.F.L. $\longrightarrow$ L.H.L. $\longrightarrow$ R.F.L. $\longrightarrow$ R.H.L. \\
\hline No. 4 & R.H.L. $\longrightarrow$ L.H.L. $\longrightarrow$ L.F.L. \\
\hline No. 5 & L.H.L. $\longrightarrow$ L.F.L. $\longrightarrow$ R.HL. \\
\hline No. 6 & L.F.L. $\longrightarrow$ L.H.L. $\longrightarrow$ R.H.L. $\longrightarrow$ P.F.L. \\
\hline No. 7 & L.H.L. $\longrightarrow$ L.F.L. $\longrightarrow$ R.H.L. $\longrightarrow$ P.F.L. \\
\hline No. 8 & L.F.L. $\longrightarrow$ L.H.L. $\longrightarrow$ R.H.L. $\longrightarrow$ R.F.L. \\
\hline No. 9 & L.H.L. $\longrightarrow$ L.F.L. $\longrightarrow$ R.H.L. \\
\hline No. 10 & L.F.L. $\longrightarrow$ L.H.L. $\longrightarrow$ R.H.L. $\longrightarrow$ R.F.L. \\
\hline No. 11 & R.H.L. $\longrightarrow$ R.F.L. $\longrightarrow$ L.F.L. $\longrightarrow$ L.H.L. \\
\hline
\end{tabular}

For example, when the focus was in the fore limb, it spread not only to the ipsilateral hind limb but sometimes to the contralateral hind limb, as well as to the contralateral fore limb. When the focus was in the hind limb, it spread not only to the ipsilateral fore $\operatorname{limb}$, but to the contralateral fore limb or hind limbs. Sometimes it spread to the direction of the clock finger, sometimes to the contrary direction. We could not also find any rule in the direction or its sequences in dogs' experiment.

As the cortex of monkeys contains motor representations in quite definite order in the surface of precentral gyrus, as is well known, and when one of the representations is stimulated, the corresponded muscle contracts. If the impulse 
spreads to the neighbouring point, the movement must occur in a muscle in reference of the mator homunculus. If so, the direction of march, in the above table, must be determined, for example as R. F. L. $\rightarrow$ R. H. L. or R. H.L. $\rightarrow$ R. F. L., it always must be $R . \rightarrow R$. But the above table rather showed that there is no such rule which accords with the motor homunculus. In other words, the motor representations have more complicated connection with each other.

2. The generalized seizure did not stop when a part included the focus was extirpated, but it stopped when the whole motor area (Area 4) was extirpated.

Any time when a point within Area 4 was stimulated and the focal seizure was generalized, or any part of Area 6 was stimulated and produced the generalized seizure, after the generalization occurred, if the whole Area 4 was extirpated, the seizure stopped suddenly, but when a part of Area 4 was removed, the seizure continued, not slightly changed. The example was shown already in Table 1. Other examples are shown in the next table.

Table 5

The generalized epileptic seizure following the stimulation of a part of area 4 continued after the extirpation of the area renaining a small part of it. (monkeys)

\begin{tabular}{|c|c|c|}
\hline Experiment No. 4 & Monkey & $3.3 \mathrm{~kg}$ \\
\hline Stimulation & $\begin{array}{l}\text { Remained part of } \\
\text { area } 4\end{array}$ & $\begin{array}{l}\text { Continuation of } \\
\text { seizure }\end{array}$ \\
\hline $\begin{array}{c}\text { Electric current } \\
3 \text { secs. }\end{array}$ & $\begin{array}{c}l e f t 4 \mathrm{a} \\
(6 \times 3 \mathrm{~mm})\end{array}$ & 115 sece. \\
\hline " & "r & $180 " \prime *$ \\
\hline $\begin{array}{l}\text { Nicotinization } \\
0.001 \mathrm{cc}\end{array}$ & $\begin{array}{l}\text { right } 4 \mathrm{c} \\
(4 \times 4 \mathrm{~mm})\end{array}$ & $230 "$ \\
\hline
\end{tabular}

* A part of the left area 4 a remained, and the stimulation was applied to the remained part, the seizure was produced from right leg and generalized to the whole body, and it continued for 108 seconds.

As the table shows, any part of Area 4 have the mechanism of the continuation of the produced seizure. It was not necessary to remain the initiated site. After the seizure was produced, the continuation of it would be made by any part, any width within the remained Area 4. In another words, any small part of the area substituted the initiated part. The results were quite the same as in dogs' experiments, the example being shown in Table 6.

This experiment tells us that the initiation will occur in the motor area, but the irradiation for the generalization of seizure does not occur in the cortex. But for the seizure which was produced in any way, all points of motor area 
have the substitution each other for its continuation. This idea is so important, and so contrary to the present conception. For if the march of the movement will occur in the pyramidal system, it has no room of irradiation except in cortex. But if the movement in epileptic seizure will occur in the extrapyramidal system, there are enough ground to be irradiated in subcortical mechanism, for

Table 6

The remained small part of the motor area could continue

the generalized epileptic seizure in dogs

\begin{tabular}{|c|c|c|c|}
\hline \multicolumn{2}{|c|}{ Experiment No. 1} & Male & $13.6 \mathrm{~kg}$ \\
\hline \multicolumn{2}{|c|}{ Stimulated point } & Removed part & $\begin{array}{c}\text { Continuation of } \\
\text { seizures }\end{array}$ \\
\hline \multicolumn{2}{|c|}{ Left gyrus postcruciatus } & $\begin{array}{l}\text { left gyrus sigmoideus } \\
\text { except } 2 \mathrm{~mm} \text {. area }\end{array}$ & 40 secs. \\
\hline \multicolumn{2}{|c|}{ Right gyrus postcruciatus } & $\begin{array}{l}\text { right gyrus sigmoideus } \\
\text { except } 4 \mathrm{~mm} \text {. area }\end{array}$ & $45 \prime \prime$ \\
\hline \multirow[t]{2}{*}{$\begin{array}{cc}\mathrm{hr} . & \min . \\
4 & 30\end{array}$} & $\begin{array}{c}\text { sec. } \\
0\end{array}$ & \multicolumn{2}{|c|}{$\begin{array}{l}\text { The above remained part of the right gyrus sigmoideus } \\
\text { was stimulated, the seizure began in the left arm and } \\
\text { generalized to the whole body. }\end{array}$} \\
\hline & 13 & \multicolumn{2}{|c|}{$\begin{array}{l}\text { During the continuation of the above seizure, the remai- } \\
\text { ned part was extirpated suudenly, the seizure ceased } \\
\text { at once. }\end{array}$} \\
\hline
\end{tabular}

pathways in the extrapyramidal system must have many stations of neuronal connection under the cortex.

\section{LAW OF POINTING ACTION OF THE MOTOR AREA IN CORTICAL SEIZURES}

1. After a subliminal stimulation was applied to Area 4, the stimulation of Area 6 would produce a focal seizure with march of movement.

Now, the motor area of Area 4 of the higher animals has two functions for epileptic seizure, the one is to initiate the seizure in a delimited part of body, the other is to substitute each other within the area for the continuation of the seizure. In Table 7 , it shows the relation of the site of the stimulation and the focus from which the seizure began, in our experiments. For example, when Area 4a was stimulated, it began from the fore limb in 16 cases among 25, and when Area 6a was stimulated, the seizure was all generalized from the beginning. We considered if any procedure the stimulation of Area 6a should produce the focal seizure, as shown in Table 8.

The stimulation applied to any point of Area 4, if the current was not so strong, first produced the tonic movement in the contralateral corresponding limb only, and it was made stronger, then the focal seizure began. In another words, 
the strength which produced the delimited tonic movement only, was to be called the subliminal stimulation for the clonic convulsion. When a point of Area 4 was stimulated, first with these subliminal current, and five seconds after, the stimulation of Area $6 a$ was done, we could get the focal seizure which began by the stimulation of Area 6a.

Table 7

The focal initiation of the seizure and stimulated point of cortex in monkey. (The platinum electrodes were used. of which the distance between anodal and cathodal was $2 \mathrm{~mm}$.)

\begin{tabular}{c|c|c|c|c|c}
\hline \multirow{2}{*}{$\begin{array}{c}\text { Stimulated } \\
\text { point }\end{array}$} & $\begin{array}{c}\text { Contralateral } \\
\text { hind limb }\end{array}$ & $\begin{array}{c}\text { Contralateral } \\
\text { fore limb }\end{array}$ & Face* & $\begin{array}{c}\text { Generalized } \\
\text { from the } \\
\text { beginning }\end{array}$ & $\begin{array}{c}\text { Total } \\
\text { cases }\end{array}$ \\
\cline { 2 - 6 } & 16 & 0 & 1 & 8 & 25 \\
Area 4a & 0 & 24 & 3 & 7 & 34 \\
Area 4b & 0 & 2 & 10 & 1 & 13 \\
Area 4c & 3 & 0 & 0 & 0 & 3 \\
Area 1-2a & 0 & 5 & 0 & 0 & 5 \\
Area 1-2b & 0 & 0 & 4 & 0 & 4 \\
Area 1-2c & 0 & 0 & 0 & 16 & 16 \\
Area 6ac & 0 & & & & \\
\hline
\end{tabular}

* See Hayashi's previous report (2).

Table 8

The stimulation of area $6 \mathrm{acx}$ produced the focal epil:ptic seizure when the conditioning stimulation was forwardly applied to area 4

\begin{tabular}{|c|c|c|c|}
\hline \multicolumn{3}{|c|}{ Experiment No. 5} & Monkey $\quad$ Female \\
\hline \multirow[t]{4}{*}{$\underset{1}{\text { hr. }}$} & $\min$. & $\begin{array}{l}\text { sec. } \\
0 \\
1\end{array}$ & $\begin{array}{l}\text { The left Area sa was stimulated with faradization of } 10 \text { seconds. } \\
\text { In the right hind limb, clcnic contraction was produced. }\end{array}$ \\
\hline & 56 & $\begin{array}{l}0 \\
1 \\
5\end{array}$ & $\begin{array}{l}\text { The left area } 6 a x \text { was stimulated } 5 \text { secs. Clonic convulsion } \\
\text { was occurred in the whole body at the same time and con- } \\
\text { tinued } 10 \text { seconds. }\end{array}$ \\
\hline & 58 & $\begin{array}{l}0 \\
1 \\
1\end{array}$ & $\begin{array}{l}\text { The left Area } 4 \mathrm{a} \text { was stimulated ( } 1.0 \mathrm{sec} \text {.). Tonic contraction } \\
\text { was produced in right hind limb. }\end{array}$ \\
\hline & & 5.5 & $\begin{array}{l}\text { Area } 6 \text { an was stimulated overlappingly } 5 \text { secs. The seizure } \\
\text { began at the right hind limb and generalized to the left } \\
\text { hind limb } \rightarrow \text { left fore } \operatorname{limb}_{\text {inght }} \text { fore limb, and continued } 49 \\
\text { seconds. }\end{array}$ \\
\hline \multirow[t]{4}{*}{2} & 0 & 4 & $\begin{array}{l}\text { The left Area 4b was stimulated }(1.0 \mathrm{sec} .) \text {, It resulted tonic } \\
\text { in the right fore limb. }\end{array}$ \\
\hline & & 9.5 & $\begin{array}{l}\text { The left Area } 6 a \text { was stimulated overlappingly. The seizure } \\
\text { began in the right fore limb and marched to both hind limbs } \\
\text { and to the left fore limb. }\end{array}$ \\
\hline & 11 & 0 & $\begin{array}{l}\text { The left Area 4c was stimulated }(1.0 \mathrm{sec} .) \text {, resulting clonic in } \\
\text { face muscle of both sides. }\end{array}$ \\
\hline & & 5.5 & $\begin{array}{l}\text { The stimulation at Area } 6 \text { a } \alpha \text { was overlapped for } 5 \text { secs. The } \\
\text { seizure began in both sides of the face and marched to the } \\
\text { right fore limb } \rightarrow \text { both sides of the hind limbs } \rightarrow \text { the left fore } \\
\text { limb. }\end{array}$ \\
\hline
\end{tabular}


The mechanism of the above conditioning phenomena, for the time being, we would call the pointing action of each site of Area 4 .

Table 9

Stimulation of area 4 did not condition a focus of the seizure produced from the contralateral area $6 \mathrm{a} \alpha$

\begin{tabular}{|c|c|c|c|}
\hline \multicolumn{3}{|c|}{ Experiment No. 6} & $\begin{array}{lll}\text { Monkey } & \text { Male } & 4.5 \mathrm{~kg}\end{array}$ \\
\hline \multirow[t]{6}{*}{ hr. } & $\min _{33}$ & $\begin{array}{c}\text { sec. } \\
0\end{array}$ & $\begin{array}{l}\text { The left area } 4 \mathrm{a} \text { was stimulated }(1.0 \mathrm{sec}) \text { subliminally for } \\
\text { clonic seizures, in the right hind limb, the tonic contraction } \\
\text { was produced. }\end{array}$ \\
\hline & & 5.5 & $\begin{array}{l}\text { Stimulation ( } 5 \text { secs.) at the left area } 6 \text { a } x \text { was overlapped } 0.5 \\
\text { seconds with the above current. The seizure was produced } \\
\text { in the whole limbs at the same time. }\end{array}$ \\
\hline & 41 & $\begin{array}{l}0 \\
\frac{1}{1}\end{array}$ & $\begin{array}{l}\text { Stimulation ( } 1.0 \text { sec.) at the left area } 4 \mathrm{~b} \text {, produced the tonic } \\
\text { contraction of the right fore limb. }\end{array}$ \\
\hline & & 5.5 & $\begin{array}{l}\text { Stimulation ( } 5.0 \text { secs.) at the right area } 6 a x \text { produced the ge- } \\
\text { neralized seizure from the beginning. }\end{array}$ \\
\hline & $44^{\circ}$ & 0 & $\begin{array}{l}\text { Stimulation (1.0 sec.) at the left area } 4 \mathrm{c} \text { produced the tonic } \\
\text { contraction of face of both sides. }\end{array}$ \\
\hline & & $\frac{1}{5}$ & $\begin{array}{l}\text { Stimulation ( } 5 \text { secs.) at the right area } 6 a x \text { produced the ge- } \\
\text { neralized seizure from the beginning. }\end{array}$ \\
\hline
\end{tabular}

Horizontal cutting was applied $6 \mathrm{~mm}$. deep under the left cortex of area 6

\begin{tabular}{|c|c|c|c|}
\hline \multirow[t]{7}{*}{2} & 46 & 0 & $\begin{array}{l}\text { The left area } 6 a \alpha \text { was stimulated (duration } 5 \text { secs.). It pro- } \\
\text { duced the generalized seizure from the beginning. }\end{array}$ \\
\hline & 48 & $\begin{array}{l}0 \\
1 \\
1\end{array}$ & $\begin{array}{l}\text { The left area } 4 \text { a was stimulated (duration } 1.0 \text { sec.). It produ- } \\
\text { ced tonic contraction in the contralateral fore limb. }\end{array}$ \\
\hline & & 5.5 & $\begin{array}{l}\text { Stimulation was applied ( } 5.0 \text { secs.) at area } 6 \mathrm{a} \alpha \text {, it produced a } \\
\text { focal seizure initiated at the right hind limb and generali- } \\
\text { zed to the right fore } \operatorname{limb} \rightarrow \text { the left fore limb } \rightarrow \text { the left hind } \\
\text { limb. }\end{array}$ \\
\hline & 49 & 0 & $\begin{array}{l}\text { The left area } 4 b \text { was stimulated }(1.0 \mathrm{sec}) \text {. It produced the } \\
\text { tonic contraction at the right fore limb. }\end{array}$ \\
\hline & & 5.5 & $\begin{array}{l}\text { The left area } 6 \mathrm{a} \alpha \text { was stimulated (duration } 5 \text { secs.). It pro- } \\
\text { duced the focal seizure initiated at the right fore } \operatorname{limb} \text {. It } \\
\text { marched to } \rightarrow \text { both sides of hind limbs } \rightarrow \text { the left fore } \operatorname{limb} \text {. }\end{array}$ \\
\hline & 50 & 0 & $\begin{array}{l}\text { The Ieft area } 4 \mathrm{c} \text { was stimulated }(1.0 \mathrm{sec} \text {, ). The tonic cont- } \\
\text { raction appeared in the face muscles of both sides during } \\
\text { the stimulation. }\end{array}$ \\
\hline & & 5.5 & $\begin{array}{l}\text { Stimulation was applied overlapping the above stimulation } \\
\text { half a second at area } 6 \mathrm{a} \alpha \text {. It produced the generalized sei- } \\
\text { zures from the beginning. }\end{array}$ \\
\hline
\end{tabular}

It meant that the impulses for tonic contraction which were produced by the stimulation of Area 4, had an action to initiate clonic seizure at a certain body part which was determined by the site of stimulation at the Area 4, by the epileptogenic stimulation of Area 6. Perhaps the impulses for clonic seizure which were produced in Area 6, at first concentrated into the impulses for tonic 
one at the conditioned point of Area 4, and then generalized as in the form of a focal seizure. Therefore each point of Area 6 must be connected to every point of Area 4 , as in the latter half of the Table 9 which shows that the horizontal severing was applied in the white matter under the cortex of Area 6, the epileptogenic action of the stimulation on the area would not be abolished, and when a point of the latter was first stimulated subliminally (for the epileptic seizure), the seizure from Area 6 would be initiated through this stimulated point of Area 4.

2. Subliminal stimulation at Area 4 had not any pointing action for the stimulation of the contralateral Area 6.

Table 10

After a part of area $1-2$ was subliminally stimulated, the stimulation of area $6 \mathrm{a} x$ produced focal seizure

\begin{tabular}{|c|c|c|c|}
\hline \multicolumn{3}{|c|}{ Experiment No. 7} & Monkey \\
\hline \multirow[t]{3}{*}{ hr. } & $\min _{23}$ & $\begin{array}{l}\text { sec. } \\
0-5\end{array}$ & The right area $1-2 \mathrm{a}$ was stimulated ( 5 secs.). no motor effect. \\
\hline & 27 & $0-5$ & The right area $1.2 \mathrm{~b}$ was stimulated, no motor effect. \\
\hline & 31 & $0-5$ & $\begin{array}{l}\text { The right area } 6 a \alpha \text { was stimulated. A generalized seizure was } \\
\text { produced from the beginning and continued } 114 \text { secs. }\end{array}$ \\
\hline \multirow[b]{3}{*}{3} & 37 & $0-10$ & $\begin{array}{l}\text { The right area } 1-2 b \text { was stimulated for } 10 \text { secs. The focal } \\
\text { seizure began at the left fore limb } \rightarrow \text { left hind limb } \rightarrow \text { right } \\
\text { hind limb } \rightarrow \text { right fore limb. The generalized epileptic seizure } \\
\text { continued for } 212 \text { secs. }\end{array}$ \\
\hline & 52 & $10-0$ & $\begin{array}{l}\text { Stimulation of area } 1-2 \text { a produced focal seizure beginning at } \\
\text { the left hind limb } \rightarrow \text { left fore limb } \rightarrow \text { right hind limb } \rightarrow \text { right } \\
\text { fore limb. It continued for } 158 \text { secs. }\end{array}$ \\
\hline & 1 & $0-10$ & $\begin{array}{l}\text { Area } 1-2 b \text { and } 6 a x \text { were stimulated at the same time for } 10 \\
\text { secs. The generalized seizure was produced from the begin- } \\
\text { ning. It continued for } 77 \text { secs. }\end{array}$ \\
\hline \multirow[t]{5}{*}{3} & 9 & $0-5$ & $\begin{array}{l}\text { The right area } 1-2 \mathrm{~b} \text { was stimulated for } 5 \text { secs., at the same } \\
\text { time, the right area } 6 \mathrm{a} \alpha \text { was stimulated for } 10 \text { secs. The } \\
\text { focal seizure was produced beginning at the left fore limb } \rightarrow \\
\text { left hind limb } \rightarrow \text { right hind limb } \rightarrow \text { right fore limb. It con- } \\
\text { tinued for } 104 \text { secs. }\end{array}$ \\
\hline & 15 & $0-5$ & $\begin{array}{l}\text { The right area } 1-2 a \text { for } 5 \text { secs, the right area } 6 a \alpha \text { for } 7 \text { secs. } \\
\text { were stimulated. The focal seizure beginning at the left } \\
\text { hind limb } \rightarrow \text { left fore limb } \rightarrow \text { right hind limb } \rightarrow \text { right fore } \\
\text { limb. It continued for } 146 \text { secs. }\end{array}$ \\
\hline & 30 & $0-10$ & $\begin{array}{l}\text { The right area } 1-2 \mathrm{c} \text { was stimulated for } 10 \text { secs. The seizure } \\
\text { began at the lips and generalized } \rightarrow \text { eyelids } \rightarrow \mathrm{LF} \rightarrow \mathrm{LH} \rightarrow \mathrm{RH} \\
\mathrm{RE} \text {, and the generalized one continued for } 130 \text { secs. }\end{array}$ \\
\hline & 40 & $0-5$ & $\begin{array}{l}\text { The right area } 1-2 \mathrm{c} \text { was stimulated for } 5 \text { secs. subliminally, } \\
\text { at the same time, the right area } 6 \text { a } \alpha \text { was stimulated for } 7 \\
\text { secs. The seizure began at the lips and generalized to the } \\
\text { eyelids } \leftarrow \mathrm{LF} \leftarrow \mathrm{LH} \rightarrow \mathrm{RH} \rightarrow \mathrm{RF} \text { and it continued } 150 \text { secs. }\end{array}$ \\
\hline & 50 & $0-5$ & $\begin{array}{l}\text { The left area } 6 \text { a } x \text { was stimulated for } 5 \text { secs. The seilure was } \\
\text { produced in the whole body from the beginning. }\end{array}$ \\
\hline
\end{tabular}


The above idea for pointing action within the cortex, is only an idea for . the time being, for it will be considered in equal rights that the conditioning may be produced in subcortical station. In this latter case, the connected side must be the same, for, the stimulation at Area 4 did not have effect to point for the seizure which will be produced by the stimulation of Area $6 \mathrm{a}$ of the contralateral cortex as shown in the former half of Table 9.

When a conditioning stimulus was applied to the Area 1-2, the result was quite the same as was conditioned at the Area 4 as shown in Table 10. The Area 1-2 is the end of the afferent pathway from the skin or muscles. Therefore, instead of the direct stimulation of Area 1-2, indirect stimulation through the peripheral nerve could establish conditioning, which will be shown in the next table. (See Table 11)

Table 11

After the peroneous nerve was stimulated, the seizure from area 6ax of the contralateral cortex became a focal type of the generalized seizure

\begin{tabular}{|c|c|c|c|}
\hline \multicolumn{3}{|c|}{ Experiment No. 8} & Monkey \\
\hline $\begin{array}{c}\text { hr. } \\
2\end{array}$ & $\min _{40}$ & $\begin{array}{l}\text { sec. } \\
0-5\end{array}$ & $\begin{array}{l}\text { The left area } 6 a \alpha \text { was stimulated. The generalized seizure } \\
\text { was produced from the beginning which continued } 363 \text { secs }\end{array}$ \\
\hline \multirow[t]{5}{*}{3} & 5 & $0-5$ & $\begin{array}{l}\text { The right peronal nerve for } 1 \text { sec., at the same time, the area } \\
6 \mathrm{a} \alpha \text { was stimulated for } 5 \text { secs. The seizure began at the } \\
\mathrm{RH} \text { and generalized to the } \mathrm{RF} \rightarrow \mathrm{LF} \rightarrow \mathrm{LH} \text { and it continued } \\
327 \text { secs. }\end{array}$ \\
\hline & 23 & $\begin{array}{l}0-1 \\
0-5\end{array}$ & $\begin{array}{l}\text { The right radial nerve was stimulated. The seizure began } \\
\text { at the right fore limb and generalized } \rightarrow \mathrm{RF} \rightarrow \mathrm{RH} \rightarrow \mathrm{LH} \rightarrow \\
\mathrm{LF} \text { and continued } 338 \text { secs. }\end{array}$ \\
\hline & 33 & $0-1$ & $\begin{array}{c}\text { The right area } 1-2 b \text { and } 6 a \alpha \text { were stimulated. The seizure } \\
\text { began at } R F \rightarrow R H \rightarrow L H \rightarrow L F \text {. It continued sy secs. }\end{array}$ \\
\hline & 35 & $\begin{array}{l}0-1 \\
0-5\end{array}$ & $\begin{array}{l}\text { The area } 1-2 \mathrm{~b} \text {. was stimulated for } 1 \text { sec., at the same time, } \\
\text { the left area } 6 \text { a } \alpha \text { was stimulated. The seizure began at } \mathrm{RH} \\
\rightarrow R F \rightarrow L F \rightarrow L H \text {. It continued } 385 \text { secs. }\end{array}$ \\
\hline & 50 & $0-5$ & $\begin{array}{l}\text { The left area } 6 a \alpha \text { was stimulated. It produced the general } \\
\text { ized type from the beginning. }\end{array}$ \\
\hline
\end{tabular}

What is the mechanism which lies under the pointing? The subliminal stimulation applied at any point of the cortex brings the conditioning to the stimulation of area $6 \mathrm{a} \alpha$, and the stimulation of nerve which contains the fibers from skin receptors as well as from stretch receptors of muscle, also brings the conditioning. Therefore it must be due to that point of the Area 4 which is stimulated by subliminal current or the point which receives the afferent impulse from a nerve. The evidence of the case consists in the fact that when the area is not excitable, the stimulation applied must not have effect of pointing. The following table will answer the question.

Thus the pointing was also due to the mechanism of cortex or subcortical 
region, not due to the evoked contraction of muscles of a limb by the application of stimulation on a peripheral nerve, nor the excitation which occurred at the stimulated part of the nerve, but it must be the excitation of the cortex which was produced by the conducted afferent impulse from the excited peripheral nerves. Therefore, the meaning of the stimulation of nerve was the same as the stimula-

Table 12

When area 4 did not have the excitability for electric current, it had no pointing

\begin{tabular}{|c|c|c|c|}
\hline \multicolumn{3}{|c|}{ Experiment No. 9} & Monkey \\
\hline hr. & $\min _{50}$ & $\begin{array}{c}\sec \\
0-4\end{array}$ & $\begin{array}{l}\text { The faradization was applied at the left area } 6 \text { a } \alpha \text { for } 5 \text { secs } \\
\text { The epileptic seizure of the generalized type from the be } \\
\text { ginning was produced and continued for } 440 \text { secs. }\end{array}$ \\
\hline \multirow[t]{4}{*}{4} & 0 & 0 & $\begin{array}{l}\text { The faradization for } 1 \text { sec. was applied at the left area } 4 \mathrm{~b} \text {. } \\
\text { Tonic movement was occurred in the right fore limb. }\end{array}$ \\
\hline & 3 & $10-30$ & $\begin{array}{l}\text { The heated small glass tube of } 100^{\circ} \mathrm{C} \text { was applied for } 20 \text { secs. } \\
\text { at the part of } 2 \times 2 \mathrm{~mm} \text {. in the left area } 4 \mathrm{~b} \text {. }\end{array}$ \\
\hline & \multirow[t]{2}{*}{4} & 5 & $\begin{array}{l}\text { The faradization for } 1 \text { sec. was applied at the part having been } \\
\text { heated of area } 4 \mathrm{~b} \text {, no movement. }\end{array}$ \\
\hline & & 9 & $\begin{array}{l}\text { The faradization for } 1 \text { sec. was applied at the left area } 4 \mathrm{~b} \text {, at } \\
\text { the same time, stimulation of } 5 \text { secs. was applied at the left } \\
\text { area } 6 a \alpha \text {. The generalized seizure from the beginning was } \\
\text { produced and continued for } 487 \text { seconds. }\end{array}$ \\
\hline
\end{tabular}

tion applied to the cortex Area 4 or 1-2.

What mechanism underlies in a fact that the stimulation at area 4 to make convergence the epileptogenic function of Area $6 \mathrm{a}$ which otherwise should produced the seizure generalized from the beginning into a focal seizure, is quite unknown. If a probable explanation may be offered, it will be that, the subliminal stimulation at Area 4 evolves the excitation at the stimulated point and at the same time, the inhibition is induced around the excited point, and the generalized impulses from the Area $6 \mathrm{a}$ can be conducted through the part of Area 4 only, and then the seizure will be transformed into a focal type. If this mechanism would be occurred in subcortical station, the explanation will also apply in the same way.

\section{DISCUSSION}

The belief hitherto held is that the Area 4 of the higher animals contains the ganglion cells of pyramidal tract and the Area 6 in the extrapyramid is not responsible for the epileptic seizures. The ganglion cells for the epileptic seizure, i.e. a system of the extrapyramidal ones, are also situated mingled with that of the pyramidal system in the Area 4. In the experimental focal seizure above mentioned, although the seizure generalized from the beginning is originated at 
the Area 6, as well as the focal seizure with march is originated from the Area 4 , the generalization must be due to the mechanism of subcortical or to the cortico-subcortical mechanism. So that the mechanism of these two seizures belongs to the extrapyramidal system.

But it is quite questionable whether or not the pointing action of the Area 4 to the seizure which is produced from the stimulation of the Area 6, as well as from the Area 4 itself, is due to the pyramidal system. The fact that after the severing of the medullary pyramid of both sides, the stimulation of the motor cortex does not abolish the production of isolated movements as well as tonic of limb, as was reported by the author(1), in which the form of movement can not be discerned as phasic or sustained, for at least, they are quite the same in dogs. Therefore in this case the phasic or short tonic movements are produced not by the pyramidal, but the extrapyramidal system.

Now, the first question is:- Is the pointing action of those phasic or short tonic system remained after the pyramid section? We made an experiment first that after severing the pyramids of both sides, the stimulation on the Area 4 could produce the focal type of the epileptic seizure or not, secondly the pointing action of Area 4 was remained or not.

For our great regret, we have had no experiments on monkeys, but the experiment on dogs showed that after severing the medullary pyramids, the stimulation of gyrus sigmoideus could produce a focal epileptic seizure with march in its generalization, and also it had the pointing action to the seizure which was produced from the extramotor area. From these results, we believe that the pointing action is not accounted only for pyramidal system, but rather for the extrapyramidal.

At any rate, in monkeys, the areas anterior to and posterior to the central sulcus produce focal epileptic seizures. Perhaps in human beings, the motor area and somato-sensory area of cortex does the same, and the areas more frontal to the motor area and more occipital from the somato-sensory will produce the generalized seizure from the beginning. If the subliminal stimulation is applied to the motor area or the somato-sensory area of monkeys, the effective stimulation to the premotor area and the other extramotor produces a focal seizure which soon generalizes over the whole body. In human beings it will do the same.

The second question is:- Are the laws above mentioned could be applied to criticize the clinical cases in human epileptics? For example, we will refer to the book of Penfield and Kristiansen (5) which deals with the initial phenomena of epileptic attacks and localizing value of seizure patterns. In this book, they 
analyzed 222 cases in which the patients suffered from focal seizures. Most of these patients have been studied and operated upon. The initial phenomena in the habitual seizures of each patient was determined, and this was then compared with the localization of the initial epileptic discharge in each case through the electric stimulation applied to look for the site to produce the fit over the cortex. Among 222 cases, in 25 cases aura of initial symptom or pattern was reproduced by cortical stimulation at operation, in 93 cases, gross pathological evidence was revealed at operation, and 4 cases had electro-encephalographic evidences. They divided the 222 cases into 6 groups according to the initial phenomena. Now we will take, for example, among them the cases of the motor phenomena ( 29 cases) and of the sensory phenomena ( 81 cases). The fact that 20 cases which were classified as "Jacksonian motor" had epileptogenic origins in the precentral gyrus (11 cases) or the postcentral ( 2 cases) and cerebral parts anterior or posterior to the central sulcus ( 7 cases), would be understood from our experimental facts that the stimulation of any point in the Area 4 produced focal seizure which generalized with march over the whole body.

In cases of simple adversive seizures in Penfield's classification, six of the seven patients had lesions in intermediate frontal cortex. It would be expected from our facts that the stimulation in frontal region of monkeys produced adversive movement without clonic convulsion, but when the stimulating current was stronger, the neighbouring face area was stimulated and produced the generalized epileptic seizures which began with adversive movements ${ }^{(21}$. That one in the seven cases of Penfield had his focus in the temporoparietal region could not be explained by simple application of the hitherto localization conception, but if a slight lesion would be localized in the frontal adversive region to discharge a subliminal effect, epileptogenic discharges from the temporoparietal lesion would combine with it, as our experimental conditioning at the Area 4 would show. (law of pointing action of the motor area) If one calls on, the other responds. Acknowledgement of the law would detect any subliminal lesion in clinical observations.

Two cases with vocalization as initial phenomena had epileptogenic lesion localized in frontal regions apart from the stimulation points producing vocalization in other patients. These contradiction would not be difficult to explain, if a slight subliminal focus would be found in region producing vocalization. The localization of initial somato-sensory phenomena were in postcentral gyrus in 24 cases and in 18 cases in central. It is expected from the hitherto localization thesories. In seven cases it was situated in precentral gyrus and in two cases in intermediate precentral. It must be personal difference, of which example 
can be found not so less in Penfield's book on cerebral localization (6). That in 3 cases it was in parietal lobe and in 1 case in temporal lobe (?) contradicted the former conception, when without law of pointing of somatosensory area for other extramotor activities. (See Table) The cases of auditory sensation, vestibular sensation, olfactory sensation or gustatory sensation as initial phenomena would be naturally explained by the fact that these regions are the extramotor area in the sense of ours which would be pointed by a subliminal epileptogenic focus of the motor area.

After all, the visual sensation as an initial phenomenon could not be explained through any law of ours, for in monkeys, the gyrus occipitalis is not included into the extramotor area as shown in Fig. 1, in another words, the stimulation of occipital region can not produce any clonic convulsion in monkeys although in dogs, it is ${ }^{(1)}$. Notwithstanding 11 patients of Penfield with visual aura had the localization of epileptogenic focus in occipital region. At any rate, physiological studies on the law of experimental epilepsy would offer some suggestion for the further neurosurgical research to make new discovery.

\section{SUMMARY}

1. In monkeys, the stimulation of the Area 4, 3-1-2 produced a focal epileptic seizure of which initial convulsion was determined by the site of stimulation within the areas.

2. On the contrary, the stimulation of the Area 6 produced the generalized epileptic seizure from the beginning, but it produced a focal one, when a point of the Area 4 was preliminarily stimulated with subliminal strength for the seizure or when a sensory nerve of body was stimulated.

3. During epileptic seizure which was produced by the stimulation of the motor or the extramotor cortex, when a part of the motor area (Area 4 in monkeys) was extirpated, the seizure was not changed, nor ceased, but the extirpation of the whole Area 4 made the seizure stop at once.

4. If the above results are related as a form of law, the first law is "the law of initiation and continuation of epileptic seizure from motor cortex". The second one is "the law of final common area for epileptic seizure from motor cortex". The third law is "the law of substitution of cortex for epileptic seizure". And the fourth law is "the law of pointing action of the motor area for the epileptogenic mode from the extramotor". 


\section{REFERENCES}

1. Hayashi T. A physiological study of epileptic seizure following cortical stimulation in animals and its application to human clinics. J. J. physiol. Vol. 3, 46-64, 1952.

2. Hayashi T. The efferent pathway of epileptic seizure for the face following cortical stimulation differs from that for limbs. J. J. physiol. Vol. 3, 306-321, 1953.

3. Hayashi T. Cortical mastication and its efferent pathway in dogs. The Keio Journal of Medicine. Vol. 1, 175-187, 1952.

4. Jackson J. H. Selected Writings of John Hughlings Jackson. Vol. I \& II. London, Hodder and Staughton Ltd. 1931-1932.

5. Penfield W. and Kristiansen K. Epileptic Seizure Patterns. Charles C. Thomas publisher, 1951.

6. Penfield W. and Rasmussen T. The cerebral cortex of man. The Macmillan Co., 1951. 